Schacter, D. L., Harbluk, J. L., Mclachlan, D. R. (1984). Retrieval without recollection: An experimental analysis of source amnesia. Joumal of Verbal Leaming \& Verbal Behavior, 23, 593-611.

Shallice, T., Evans, M. E. (1978). The involvement of the temporal lobes in cognitive estimation. Cortex, 14, 294-303.

SQUiRE, L. R. (1982). Comparisons between forms of amnesia: Some deficits are unique to Korsakoff's syndrome. Journal of Experimental Psychology: Learning, Memory, \& Cognition, 8, 560-571.

Squire, L. R. (1987). Memory and brain. New York: Oxford University Press.

Stuss, D. T., Kaplan, E. F., Benson, D. F., Weir, W. S., Chiull, S., a Sarazin, F. F. (1982). Evidence for involvement of orbito-frontal cortex in memory functions: An interference effect. Journal of Comparative \& Physiological Psychology, 96, 913-925.

WEEKS, D. J. (1988). The anomalous sentences repetition test. Atlantic Highlands, NJ: National Foundation for Educational Research.

Winocur, G., Moscovitch, M., * Witherspoon, D. (1987). Contextual cuing and memory performance in brain-damaged amnesics and old people. Brain \& Cognition, 6, 129-141.
Winocur, G., Oxbury, S., Roberts, R., Agnetti, V., a Davis, C. (1984). Amnesia in a patient with bilateral lesions to the thalamus. Neuropsychologia, 22, 123-143.

\section{NOTES}

1. The term short-term memory is not meant to imply that this paradigm loads specifically on a putative short-term storage or primary memory system. Use of the term is purely descriptive, denoting the relatively short periods of time over which retention is tested.

2. The subjects were further required to classify the subjective experience associated with each of these recognition responses. These data are not relevant to the present study, but they can be found in Parkin and Walter (1991).

(Manuscript received November 26, 1990; revision accepted for publication February 13, 1991.)

\title{
Forthcoming Psychobiology Articles
}

The following is a list of forthcoming Psychobiology articles that are currently in press. They are given in approximate order of acceptance. Each entry includes the name and address of the author with whom to communicate for further prepublication information.

"Effects of the peripheral 5-HT2 antagonist xylamidine on consummatory behaviors"' by S. Edwards \& R. Stevens (S.E., AFRC Institute of Food Research, Shinfield, Reading, Berkshire RG2 9AT U.K.)

"Prenatal protein malnutrition impairs visual discrimination learning in adult rats" by J. Tonkiss, J.R. Galler, B. Shukitt-Hale, \& F.J. Rocco (J.T., Ctr. for Behv'l. Devel. \& Mental Retardation, M921, Boston Univ. School of Medicine, 80 E. Concord St., Boston, MA 02118)
"How does the rat (Rattus norvegicus) adjust food-carrying responses to the influences of distance, effort, predatory odor, food size and food availability?" by I.Q. Whishaw \& H.C. Dringenberg (I.Q.W., Dept. of Psychology, Univ. of Lethbridge, 4401 University Dr., Lethbridge, AB, Canada T1K 3M4)

"Evocation in paradoxical sleep of a hippocampal conditioned cellular response acquired during waking" by $\mathrm{C}$. Maho, E. Hennevin, B. Hars, \& S. Poincheval (E.H., LPN2, C.N.R.S., 91198 Gif-sur-Yvette Cedex, France) 